\title{
Notes on rediscovery, typification and threat assessment of Veratrilla burkilliana (Gentianaceae) from Eastern Himalaya, India
}

\author{
Subhajit Lahiri and Sudhansu Sekhar Dash ${ }^{* 1}$ \\ Central National Herbarium, Botanical Survey of India, Howrah, West Bengal 711103, India \\ 'Botanical Survey of India, 3rd MSO Building, $6^{\text {th }}$ Floor, CGO Complex, DF Block, Sector-1 \\ Salt Lake, West Bengal 700064, India \\ *Corresponding author: ssdash2002@gmail.com
}

\section{भारत में पूर्वी हिमालय से ज्ञात वेराट्रिल्ला बुर्किलियाना (जेंशिएनेसी) के पुनःअन्वेषण, प्ररूपण एवं इसके संभावित संकट के निर्धारण पर लेख सुभाजित लाहिड़ी, सुधांसु शेखर दास}

\begin{abstract}
सारांश
वेराट्रिल्ला बुर्किलियाना (डब्लू डब्लू. रिम्म.) (जेंशिएनेसी) जो अभी तक अपने मूलस्थान से ही ज्ञात है, इसे कम से कम 108 वर्षों के अंतराल के बाद पुनः अन्वेषित किया गया है। इसकी संख्या एवं संरक्षण अवस्था, सवितरण परिसर एवं नाम स्वेरशिया बुर्किलियाना का प्ररूपण सहित सवितरण मानचित्र जहाँ इसके संभावित संकट अवस्था को संकटग्रस्त रूप में निर्धारित किया गया है, ये सभी चीजें प्रदान कि गई हें। इसके सुगम पहचान हेतु इस जाति के छायाचित्र के साथ-साथ इसके पुष्पीय भागों के विच्छेदन के भी छायाचित्र प्रदान किए गए हैं। इसका पुनःअन्वेषण इस बात के महत्त्व को दर्शाता है कि क्योंगनोसोला अल्पाइन अभयारण्य एवं पूर्वी सिक्किम स्थित इसके आस-पास के क्षेत्र जो त्रुटिपूर्ण रूप से प्रतिदर्शित हैं एवं उच्च जैवविविधता वाले क्षेत्र हैं, अभी भी यहाँ और भी फिल्डवर्क किया जाना है साथ ही यह पूर्वी हिमालयी फ़्लोरा के उच्च लुप्तप्राय जातियों के तात्कालिक संरक्षण की आवश्यता पर भी जोर डालता है।
\end{abstract}

\begin{abstract}
Veratrilla burkilliana (W.W. Sm.) Harry Sm. (Gentianaceae), hitherto known only from type locality has been rediscovered after at least a lapse of 108 years. Comments on its population and conservation status, distribution range and typification of the name Swertia burkilliana are provided, together with a distribution map where the threat status has been assessed as 'Endangered'. Field photographs of the species with dissected flowering parts are also been provided for its easy identification. This rediscovery highlights the importance of further fieldwork in poorly sampled and highly biodiverse regions of Kyongnosla Alpine Sanctuary and its neighbouring areas of East Sikkim, as well as emphasizes the urgent need for conservation of the highly threatened eastern Himalayan flora.
\end{abstract}

Keywords: Lectotypification, rediscovery, Sikkim, threat assessment, Veratrilla burkilliana

\section{INTRODUCTION}

As a part of our plant exploration work in the project "Conservation of threatened plants in Indian Himalayan region: recovery and capacity building" under "National Mission on Himalayan studies" in
Kyongnosla Alpine Sanctuary, East Sikkim, recently we came across seven gregarious patches of an interesting plant at an altitude of $3700-3865 \mathrm{~m}$ asl. On critical scrutiny of the collected specimens with literature (Smith, 1911; Smith, 1970; Aitken, 1999; Clarke, 1883; Ho \& Pringle, 1995; Maity \& al., 2018; 
Singh \& al., 2019) and comparison with herbarium specimens housed at A, ARUN, BM, BSHC, CAL, E, GH, HT, K (acronyms follow Thiers, 2020) it was identified as Veratrilla burkilliana (W.W. Sm.) Harry Sm. (Gentianaceae) hitherto known only from its type locality. Pursuance of literature have also revealed that, the species was originally collected from Changu and Fieunggong by W.W Smith (collection no 3160, 3556, 3872,4244 ) housed at CAL, E and $\mathrm{K}$ and no subsequent collection of the species was reported since its last collection by Ribu and Rhomo from Changu, $12000 \mathrm{ft}$., Sikkim on 26.10.1910 (Ribu \& Rhomo 4376; CAL!). Therefore, the present report constitutes the basis of rediscovery (S. Lahiri \& S.S. Dash 95702 CAL!) of the species from Indian territory after a lapse of 108 years. A brief description, comments on its population and conservation status, distribution range and typification of the name Swertia burkilliana (basionym of Veratrilla burkilliana) are provided along with a field photograph, photo plate of dissected floral parts and distribution map. For the selection of lectotype, the protologue have been compared with original materials. The most complete and informative specimen (W.W. Sm. 3160, K000854330) was selected (Art. 9.4 of the ICN, Turland \& al., 2018) for the lectotype.

\section{TAXONOMIC TREATMENT}

Veratrilla burkilliana (W.W. Sm.) Harry Sm., Grana Palynol. 7(1): 145. 1967.

Synonym: Swertia burkilliana W.W. Sm., J. Proc. Asiat. Soc. Bengal 7(3): 78. 1911.

Type: W.W. Smith, 3160 [lectotype designated here, K000854330, digital image!)], INDIA: Sikkim, Changu, 12000 ft., July 07, 1910.

(Fig. 2)

Plants annual, monoecious, stem erect, $20-40 \mathrm{~cm}$ high, sub quadrangular. Basal leaf simple, membranous, elliptic-spatulate, $6-11 \times 2-2.2 \mathrm{~cm}$, base attenuate, margin entire, obtuse at apex, petiole $10-12 \mathrm{~cm}$ long. Cauline leaves up to 6 pairs, ovate to elliptic or oblongelliptic; 4-6 $\times 2-2.5 \mathrm{~cm}$, acute at apex, lateral nerves 2 pairs, glabrous. Inflorescence axillary paniculate cymes, male flowers much crowed, pistillate flowers laxly arranged; flowers tetramerous, $8-10 \mathrm{~mm}$ across; pedicel 1.5-2.2 mm long, quadrangular. Calyx 4-lobed; sepals triangular-lanceolate, $1.5-3 \times 1-1.5 \mathrm{~mm}$, obtuse, entire. Corolla 4-lobed; lobes oblanceolate or oblong, 5-7 $\times$ 2-3 mm, entire or slightly undulate at margin, apex rounded or minutely emarginated, each lobe with one bluish glandular patch at middle, glands emarginated at apex. Stamens 4, perfect in male flowers; filaments linear, 1.5-2.2 mm long; anther oblong, 1.2-1. $5 \mathrm{~mm}$ long; reduced to staminode in female flower, ca. $1 \mathrm{~mm}$ long. Ovary ovoid, style minute or absent; stigma bifid, pistils abortive in male flowers. Capsule ovoid, 1-1.5 cm long.

(Fig. 1)

Flowering and fruiting.-: July-October.

Specimens collected: Sikkim: East district, Fringe area of Kyongnosla Alpine Sanctuary, 3865 m, 06.07.2019, S. Lahiri and S. S. Dash 95702 (CAL!); Latitude and longitude: $27^{\circ} 23^{\prime} 41.38^{\prime \prime} \mathrm{N} ; 88^{\circ} 42^{\prime} 46.97^{\prime \prime} \mathrm{E}$.

Distributional notes: The genus Veratrilla Baill. ex Franch. (Gentianaceae) comprises only two species; of which Veratrilla baillonii Franch. is having a wider distribution i.e., from Eastern Himalaya to its adjacent regions particularly the Yunnan province of China (POWO, 2021) while Veratrilla burkilliana shows a restricted distribution only in eastern Himalaya (Bhutan, Sikkim, Tibet Autonomous Region).

\section{TYPIFICATION OF NAME}

While studying the pollen morphology of Gentianaceae, Harry Smith (1976) shifted Swertia burkilliana to genus Veratrilla Baillon ex Franch. and proposed a new combination Veratrilla burkilliana (W.W.Sm.) Harry. Sm. While doing so, he had not mentioned anything about the type of this species, thus automatically ascribed to the type of Swertia burkilliana W.W. Sm. W.W. Smith (1911), based on his own collection from Changu, Sikkim, described a new species Swertia burkillina in J. Proc. Asiat. Soc. Bengal. He cited in the protologue "Ad ripas lacus changu dicti et apud Fieunggong 12-13000 ped. Alt. Smith, 3160, 3556, 3872, 4244." Therefore, it is evident from the protologue of Swertia burkilliana that it was based on four gatherings and therefore the name needs a lectotypification. During our study, we traced twelve specimens, three at K (K000854329; K000854330; K000854331 digital images!); three at E (E00001981; E00001982; E00001983 digital images!); and six at CAL (CAL0000018349!; CAL0000033878!; CAL0000033879!; CAL0000033880!; CAL000003381!; CAL000003382!). Among these gathering we could trace four sheets bearing collection number 3160 , four sheets bearing 3872 , two sheets with collection number 3556 and two sheets with collection number 4244 . Of these twelve specimens, the one collected by W. W. Smith from Changu, Sikkim with barcode K000854330 (Fig. 2) closely corresponding with the protologue 


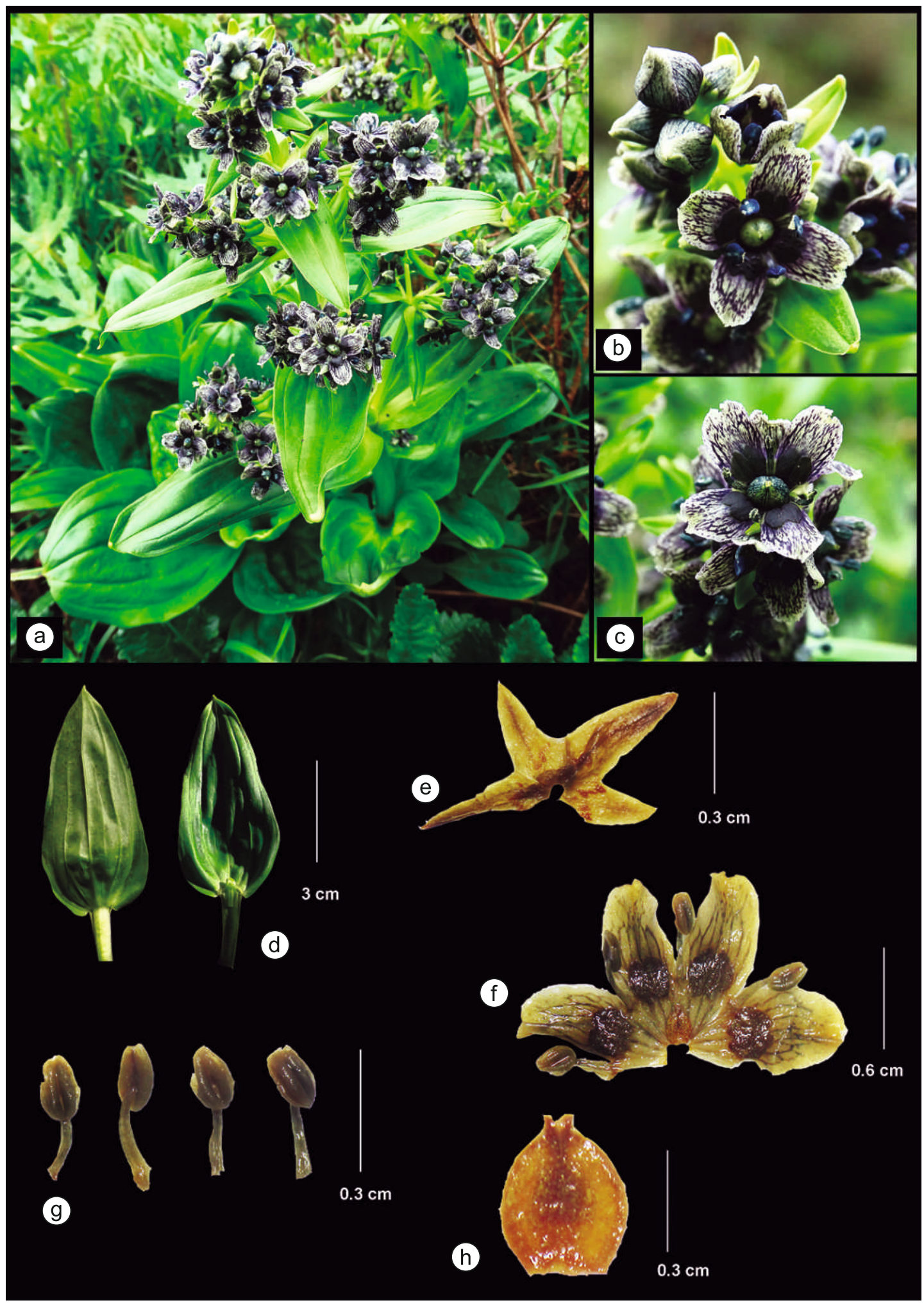

Fig. 1: Veratrilla burkilliana (W.W. Sm.) Harry Sm. a. Habit; b. \& c. Flowers; d. Abaxial and adaxial sides of leaf; e. Calyx (split opened); f. Corolla with Stamens (spilt opened); g. Stamens; h. Pistil 


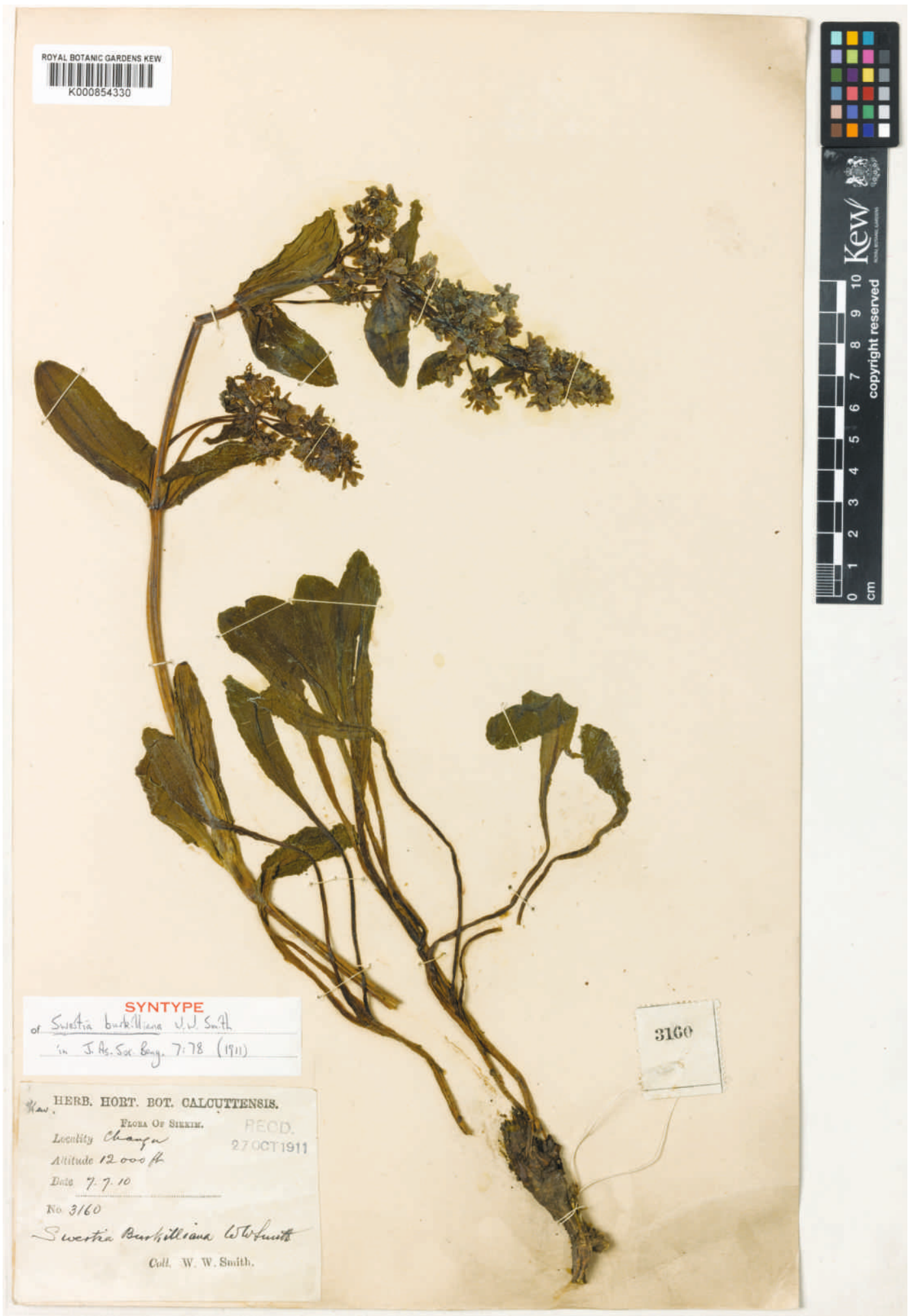

Fig. 2: Scanned image of designated lectotype of Swertia burkilliana (K000854330).

(Reproduced with the kind permission of The Board of Trustees of Royal Botanical Gardens, Kew®) available at: http://specimens.kew.org/herbarium/K000854330. Accessed on 31.01.2021 


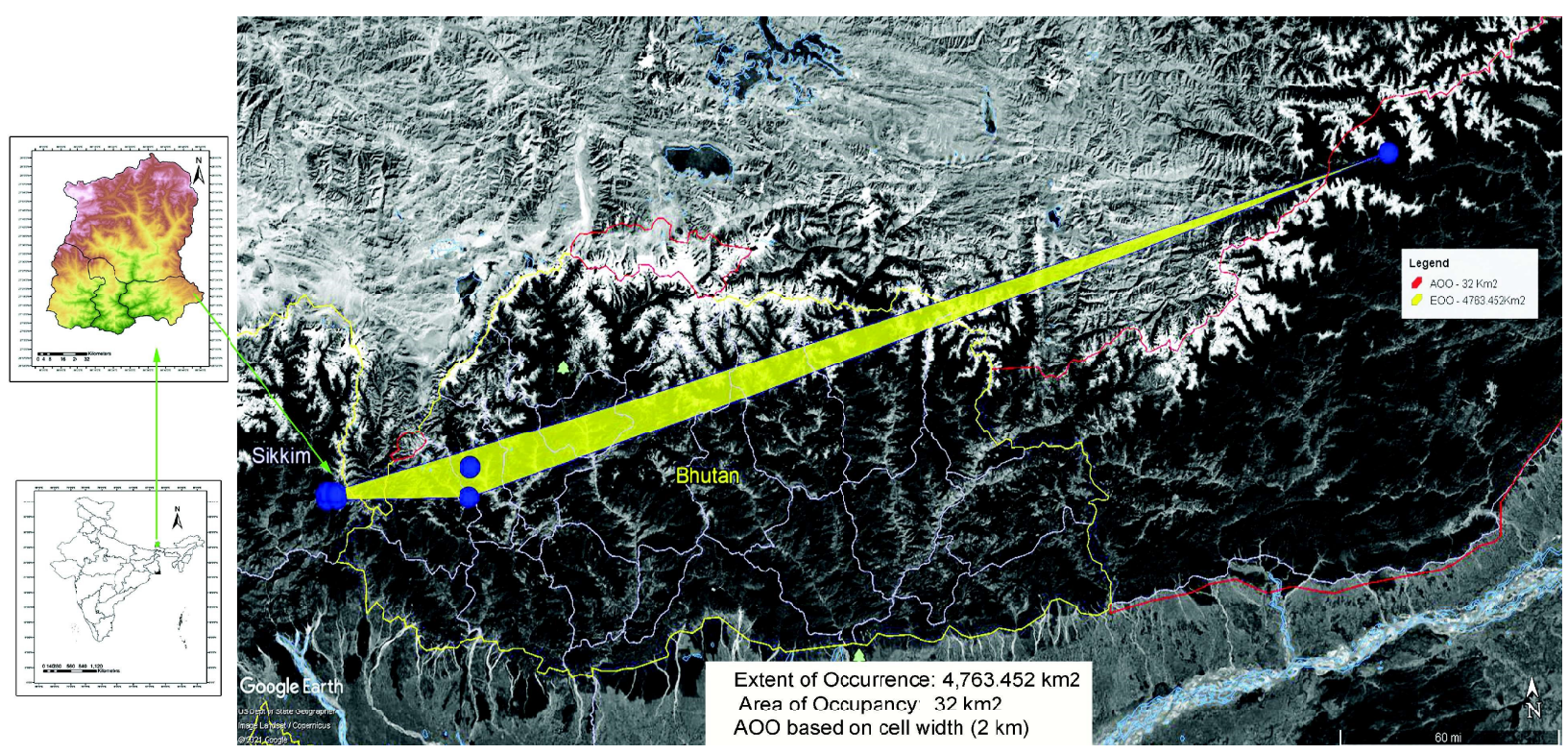

Fig 3: Map showing the study area and geographic range of Veratrilla burkilliana (W.W.Sm.) Harry.Sm.

unambiguously, therefore chosen here as the lectotype (Art. 9.4 of the ICN, Turland \& al. 2018) of Swertia burkilliana.

\section{NOTES OF CONSERVATION STATUS}

During our study, we have located seven gregarious occurrences of Veratrilla burkilliana in Kyongnosla Alpine Sanctuary, East district, Sikkim between the range of 3700-3865 m asl. Each isolated occurrence points were consisting of 8-12 plants in various flowering stages in its natural habitat. There is no data available on its historical population size and decline. Beside the Sikkim Himalaya, the species was also previously recorded from Tsari, Tomtsang of S.E Tibet (23.06.1936, Ludlow and Sherriff 2204), Chubumbu La, Langong (13.09.1936, Ludlow and Sherriff 2578) and Pung La (9.07.1949, Ludlow, Sherriff and Hicks 20903) of Bhutan (Smith, 1970). Therefore, during the study, we would consider total four sub populations (Kyongnosla alpine sanctuary as one subpopulation spread in seven occurrence points; Changu as another sub-population spread in two occurrence point; Tomtsang and Chubumbu La as third sub population spread in two occurrence point and Pung La as fourth sub population spread in one occurrence point across the eastern Himalaya. The geographical co-ordinates of each sub-populations were recorded during the survey. No data on the population size of previous colonial collections were available. Therefore, only the geographic co-ordinates of the collected localities were taken in to consideration to estimate the geographic range of this species (Moat, 2007) through Conservation Assessment Tool (CAT) developed by the Royal Botanic Gardens, Kew, UK. We used the CAT as an extension for ArcView 3.x, version 1.2, which is used to calculate the extent of occurrence (EOO) and the area of occupancy (AOO) for rapid conservation assessments based on IUCN Categories and Criteria (Fig.3). When all the data were interpreted, the $\mathrm{EOO}$ of the species Veratrilla burkilliana is calculated to $4,763.452 \mathrm{~km}^{2}$ and area of occupancy (AOO), is calculated to $32 \mathrm{~km}^{2}$.It is also imperative to mention that, the species has a very short span of life cycle; this could be one of the reasons that, it has been escaped from the sight of other plant collectors for such a long time. There is also no evidence of any commercial trade or exploitation of this species for any purpose. Therefore, due to the restricted distribution, rare occurrence, and declining quality of habitat, the threat status for Veratrilla burkilliana in Indian perspective can be assessed as 'Endangered' [EN B1ab (iii) + 2ab(iii)] (IUCN, 2012a; 2012b; 2019).

\section{ACKNOWLEDGEMENTS}

Authors are thankful to Dr. A.A. Mao, Director, Botanical Survey of India, Kolkata for providing necessary facility; PCCF, Department of Forest, 
Government of Sikkim for giving permission and logistic support; curators of Royal Botanical Garden Kew and Edinburgh for providing digital image of type specimens. Authors are also thankful to Ministry of Environment, Forest \& Climate Change (MoEF\&CC), New Delhi for financial Assistance under "National Mission on Himalayan Studies" Scheme. (Project No: NMHS2017-18/LG10/03 dated 01.04.2018).

\section{REFERENCES}

AITKEN, E. 1999. Gentianaceae. In: Long D.G. (Eds.) Flora of Bhutan Vol. 2, Part 2. Royal Botanic Garden Edinburgh and Royal Government of Bhutan. pp. 602654.

CLARKE, C.B. 1883. Gentianaceae. In: Hooker J.D. (Eds.) The Flora of British India Vol. 4. L. Reeve \& Co., London. pp. 93-132.

HO, T.N. AND J. S. PRINGLE, 1995. Gentianaceae. In: Wu Z.Y., Raven P.H. (Eds) Flora of China Vol.16. Beijing \& St Louis: Science Press \& Missouri Botanical Garden. pp. 1-139.

IUCN 2012a. IUCN Red List Categories and Criteria: Version 3.1. Second edition. Gland, Switzerland and Cambridge, UK.

IUCN 2012b. IUCN Guidelines for Application of IUCN Red List Criteria at Regional and National Levels: Version 4.0. Gland, Switzerland and Cambridge, UK.

IUCN 2019. IUCN Standards and Petitions Committee. Guidelines for Using the IUCN Red List Categories and Criteria. Version 14. Prepared by the Standards and Petitions Committee. Gland, Switzerland, 2019. http: / / www.iucnredlist.org/documents / RedListGuidelines.pdf.
MAITY, D., G.G. MAITI, AND A. S. CHAUHAN, 2018. Vascular plants of Kanchenjunga Biosphere Reserve, Sikkim. Botanical Survey of India. Kolkata, India. pp. 925.

MOAT, J. 2007. Conservation assessment tools extension for ArcView 3.x, version 1.2. GIS Unit, Royal Botanic Gardens, Kew. http://www.rbgkew.org.uk/gis/cats.

POWO: Plants of the World Online. Facilitated by the Royal Botanic Gardens, Kew. Published on the Internet. http://www.plantsoftheworldonline.org/ [Retrieved 28.01.2021].

SINGH, P., S.S. DASH, B.K. SINHA, 2019. Plants of Indian Himalayan region (An annotated Checklist \& Pictorial Guide) Part I. Botanical Survey of India (National Mission on Himalayan Studies) Kolkata, India. pp. 448.

SMITH, H. 1970. New or little known Himalayan species of Swertia and Veratrilla (Gentianaceae). Bull. br. Mus. nat. Hist. Bot 4: 237-258.

SMITH, W.W. 1911. A new Gentian and two new Swertias from the East Himalaya. J. Proc. Asiat. Soc. Bengal 7(3): 77-79.

THIERS, B. 2020. Index Herbariorum: A global directory of public herbaria and associated staff. New York Botanical Garden's Virtual Herbarium (continuously updated). Available from: http://sweetgum.nybg.org/ ih/

TURLAND, N. J., J. H. WIERSEMA, F. R. BARRIE, W. GREUTER, D. L. HAWKSWORTH, P. S. HERENDEEN, S. KNAPP, W.H. KUSBER, D.Z. LI, K. MARHOLD, T. W. MAY, J. MCNEILL, A. M. MONRO, J. PRADO, M. J. PRICE, AND G. F. SMITH. 2018. International Code of Nomenclature for algae, fungi, and plants (Shenzhen Code) adopted by the Nineteenth International Botanical Congress Shenzhen, China, July 2017. 